- Note

\title{
Fundamental Study on Ataxic Mice (Wriggle mouse Sagami).
}

\author{
Kyoko MATSUI, Masakuni MUKOYAMA, \\ Koshin ADACHI, and Kazuya ANDO. \\ National Institute of Neuroscience 4-1-1 Ogawa-Higashi- \\ Machi, Kodaira, Tokyo, 187, Japan
}

(Received 23 July 1986/Accepted 6 December 1986)

\begin{abstract}
Wriggle mouse Sagami (WMS), a newly discovered BALB/C mouse strain, is characterized by its locomotor instability, abnormal gait pattern and neck wriggling. Although the growth of WMS mice is delayed, compared with normal BALB/C mice, the brain size corresponds to the relatively smaller body weight. In gross or histological examinaitions no local atrophy appears in the cerebrum, cerebellum, brain stem or spinal cord. The c-GMP level in the WMS cerebellum is decreased, but the c-AMP level is normal. The ataxic gait is not improved significantly by the administration of thyrotropin releasing hormone (TRH). These results indicate that the mechanism inducing ataxia and abnormal gait pattern in WMS may be differerent from those in other genetically-determined ataxic mice, e. g., Rolling mouse Nagaya (RMN), PCD, Staggerer and Reeler.
\end{abstract}

\section{運動失調マウス（Wriggle mouse Sagami）の病態に関する研究}

松井京子・向山昌邦・足立皓岑·安藤一也

\section{国立精神・神経センター，神経研究所}

Wriggle mouse Sagami (WMS) は1984年大村実験 動物研究所に於て近交系として維持された $\mathrm{BALB} / \mathrm{c}$ 繁 殖コロニーから発見された，歩行障害と不随意運動を呈 する新しいミュータントマウスで, 常染色体劣性遺伝の 形式をとる。我々はこの WMS の病因を解明するため に形態学的, 行動学的, 生化学的に検討した。また遺 伝性運動失調マウスに甲状腺刺激ホルモン放出ホルモン (TRH : thyrotropin releasing hormone) を投与すると 運動失調改善効果がみられる [2]ので，WMS に対して
も $\mathrm{TRH}$ を投与し，運動失調に関する影響についてあ検 討した。

供試動物および飼育環境：4〜12週秢 WMS，および 刘照マウスとして BALB/c 系マウスを用いた。これら のマウスは温度 $24 \pm 1^{\circ} \mathrm{C}$, 湿度55～60\%の環境下で飼育 し，固型飼料F-1（三協ラボサービス）に水道水を含ま せた練り餌として自由摄取させた。

測定：12週㱓 WMS $(\mathrm{n}=8)$ の体重を測定すると, WMS は対照マウスの約 70\%であった（Fig. 1)。成長 


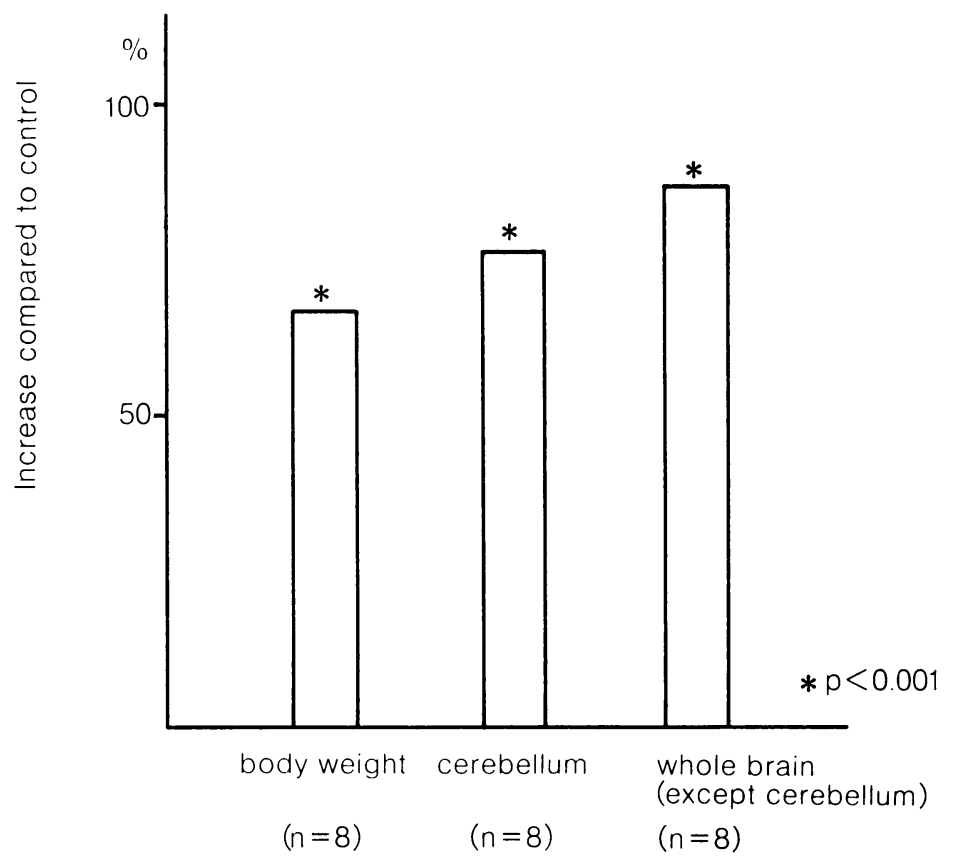

Fig. 1. Body anh brain weights of WMS mice. Percentages ompared with normal BALB/c mice 12 weeks old.

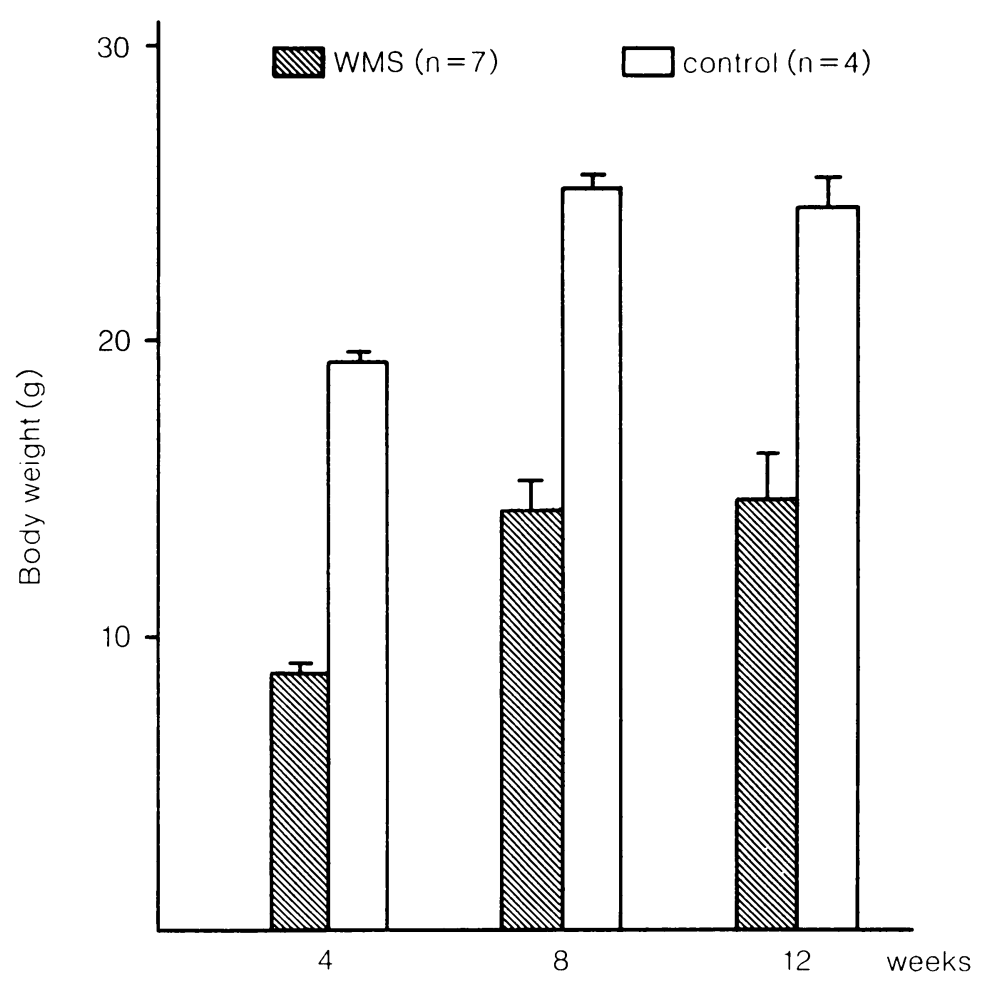

Fig. 2. Comparison of the body weights of control and WMS mice 4, 8 and 12 weeks old (meam \pm S. E.). 


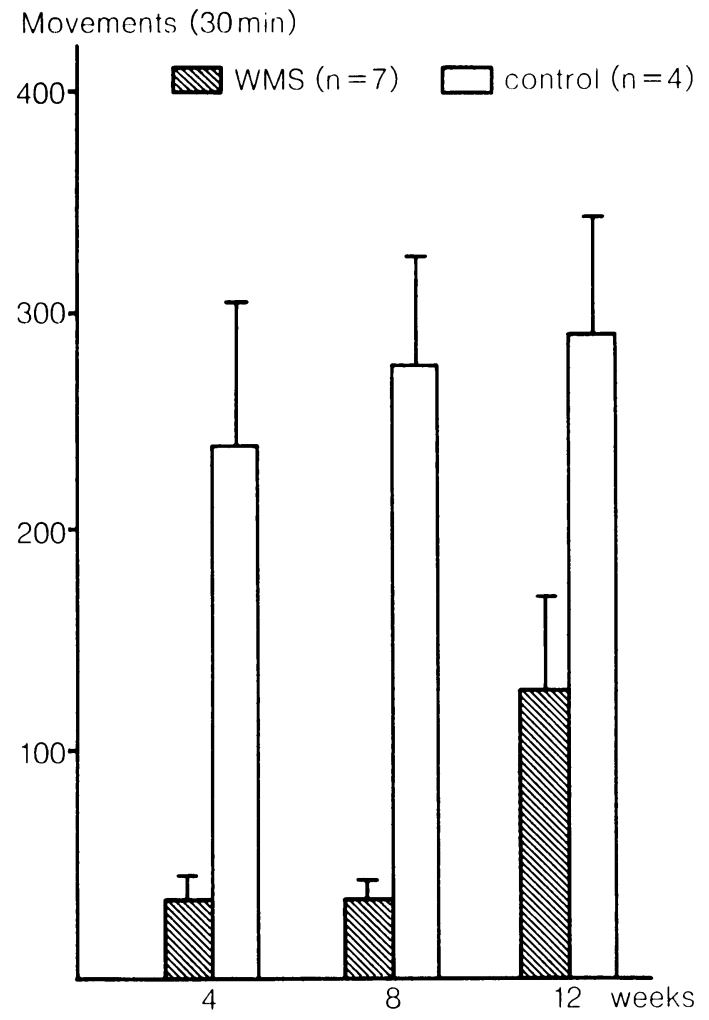

Fig. 3. Comparison of movements of control and WMS mice 4, 8 and 12 weeks old (mean \pm S. E. . .

による体重の変化を検討すると, WMS $(n=7)$ は対照 マウス $(\mathrm{n}=4)$ と同様に $4 \sim 8$ 週齢にかけて増加し, 8 〜12週歯にかけては明らかな変化はみられなかった (Fig. 2)。12週秢 WMS $(n=8)$ の脳を観察すると, 特 定の部位の萎縮は認められず, 小脳重量, 全脳（小脳を 除く）重量は対照マウス（n=8）に比へ，それぞれ約 80,90\%であった (Fig. 1)。

病理組織学的所見：脳および脊䯣をホルマリン固定, パラフィン包埋後, HE (hematoxylin-eosin), KB (Klüver-Barrera), Bodian 染色標本を作成し, 病理組 織学的に検索した。大脳, 小脳, 脳幹, 脊髄のどの部位 にあ異常を認めなかった。

行動観察：4〜12週齢WMS $(n=7)$ をオープンフィ ールド (1 区画 $\left.10 \mathrm{~cm} \times 10 \mathrm{~cm}, 70 \mathrm{~cm}^{2}\right)$ 上において行動 を観察し，さらに5 分毎に30分間にわたる移動量と転倒 回数を計測し，運動失調の程度を表わす指標として転倒 指数（転倒回数/移動量）を算出した。WMS の行動は

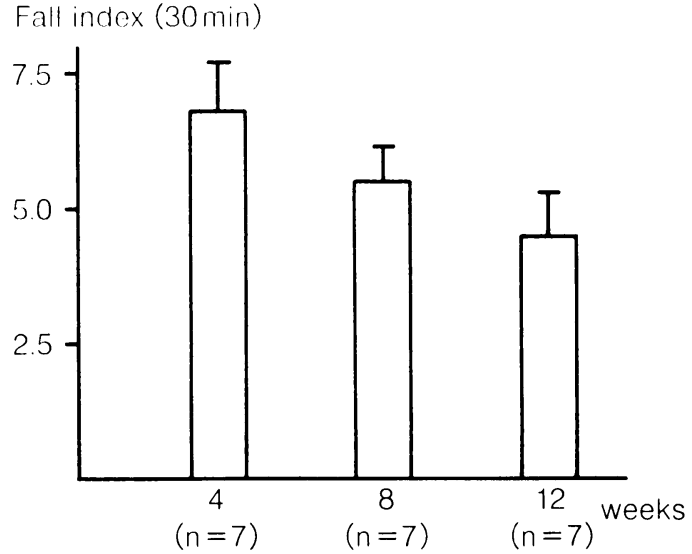

Fig. 4. Changes in fall index of WMS mice at 4, 8 and 12 weeks old (mean \pm S. E.).

緩慢で，歩行時にたびた転倒と自力での起き上がりをく り返し，左右いずれにあ転倒した。後肢を使っての立上 がりは不可能で，たびたび特有な首振り運動を行ない, 就寝時には体を横にし, 正常な姿勢の保持が困難であっ た。 4,8 週㱓WMS $(n=7)$ の移動量は対照 マウス ( $\mathrm{n}=4$ ) の約 $30 \%$ で，12週秢時には約50\%であった（Fig. $3)$ 。WMS $(n=7)$ の転倒指数は発達とともに低下傾向 を示した (Fig. 4)。

小脳 cyclic nucleotide 濃度: 12週粭 WMS $(\mathrm{n}=8$ 〜 10）および対照マウス（n=10～12）にマイクロウエー ブ照射（東芝，TMW-6402A，3.5kW 0.8〜1.3秒）後, 淔ちに小脳を取り出し，6\% TCA（トリクロル酢酸）で ホモジナイズし，上清の TCA を水飽和 エーテルで抽 出除去後, ヤマサc-GMP (cyclic $3^{\prime}, 5^{\prime}$ guanosine monophosphate), c-AMP (cyclic $3^{\prime}, 5^{\prime}$ adenosine monophosphate) キットで radioimmunoassay 法[3]に より測定した。WMS の小脳 c-GMP 濃度は対照マウ スに比へ有意 $(\mathrm{p}<0.001)$ な低下を示したが，小脳 $\mathrm{c}$ AMP 濃度は明らかな差はみられなかった（Fig. 5)。

$\mathrm{TRH}$ 投与による行動薬理学的検索：12 週 齢 WMS $(\mathrm{n}=7)$ に TRH $25 \mathrm{mg} / \mathrm{kg}$ あるいは対照の生理食塩水 を腹腔内投与後オープンフィールド上における WMS の移動量と転倒回数を 5 分每に30分間にわたり計測し た。WMS に TRH を投与すると，生理食塩水投与に 比べ転倒指数には明らかな差はなく，移動量は有意 $(\mathrm{p}$ <0.05）に低下した（Fig. 6)。

我々は Rolling mouse Nagoya (RMN), Purkinje cell degeneration (PCD), Staggerer, Reeler などの遺 

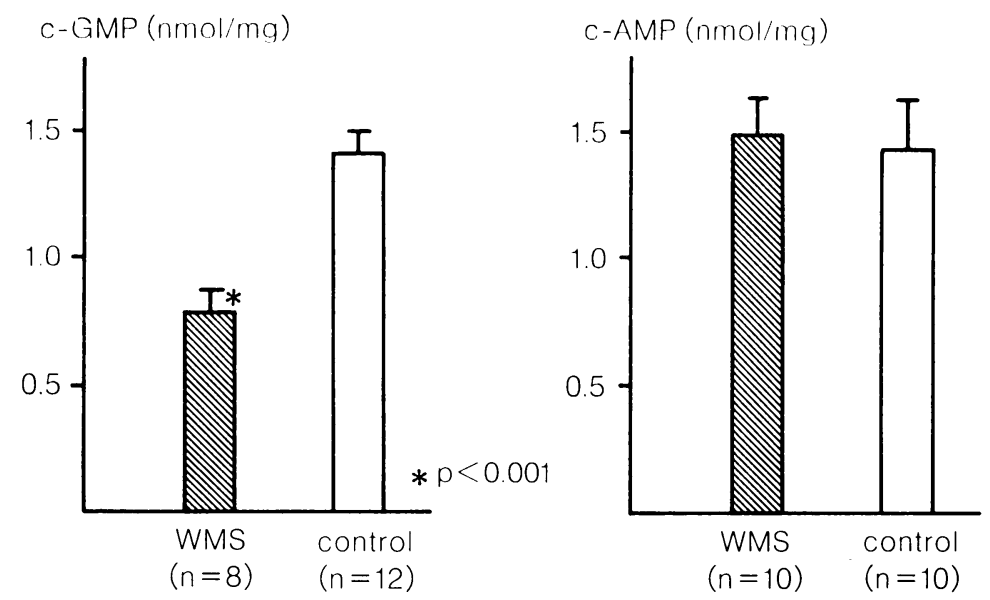

Fig. 5. Comparison of cerebellar concentrations of c-GMP and c-AMP in control and WMS mice 12 weeks old (mean \pm S. E.).

Fall index (30 $\mathrm{min})$
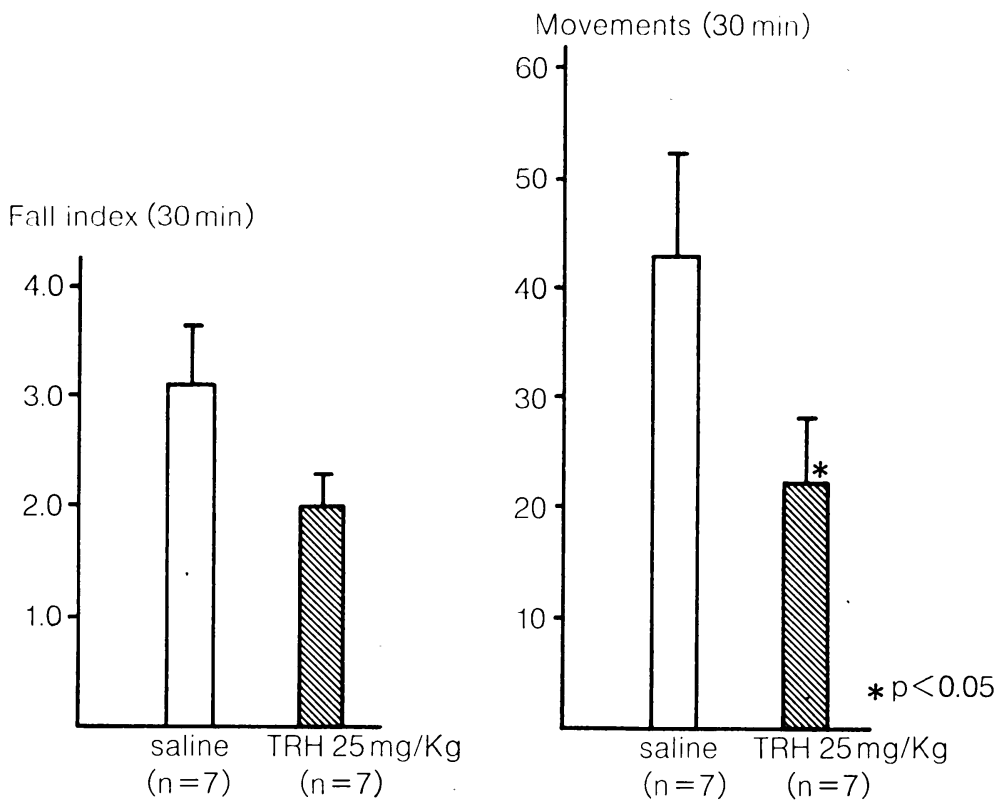

Fig. 6. Comparison of the fall index and movements in salin-and TRHtreated WMS mice 12 weeks old (mean \pm S. E.).

伝性運動失調マウスを形態学的, 生化学的, 行動薬理学 的に検索してきた $[1,2 ， 4 ， 5 ， 6]$ 。乙れらの既存の遺 伝性運動失調 マウスとWMS の類似点は (1) 歩行時に 転倒しやすいとと，(2)小脳 c-GMP 濃度の著しい低下 がみられるが, 小脳 c-AMP 濃度は正常であるとと, (3) RMN と同様に病理組織学的に中枢神経に異常を認
めないことなどである。相異点としては (1) WMS は他 の運動失調マウスにはみられない特有な首ふり運動がみ られること，(2) WMS は他の運動失調マウスにみられ るような TRH による明らかな運動失調改善がみられな いことである。こうした点から WMS の病態は従来の 遺伝性運動失調マウスのものとは異なっていると思われ 
る。

TRH は一般的にはドーパミン系を介して行動量を光 進させる作用を有するが [7], WMS はその逆に行動量 が低下し，さらに Second messenger とされている[8] c-GMP 濃度の低下などから, 神経伝達物質の変動につ いてト分考えられ, この運動障卢の発現機構について今 後さらに詳細な検封が必要である。

\section{要約}

新しく発見された BALB $/ \mathrm{c}$ 系 Wriggle mouse Sagami (WMS) は著しい運動失調と不随意運動抒よび 行動量の低下を示す特異なマウスである。対照マウスに 比べ, 大脳・小脳・脳幹・脊䯣に病理組織学的異常を認 めない。小脳 c-GMP (cyclic $3^{\prime}, 5^{\prime}$ guanosine monophosphate) 濃度は低下したが，小脳 c-AMP (cyclic $3^{\prime}, 5^{\prime}$ adenosine monophosphate) 濃度は変化を示さな い。 thyrotropin releasing hormone (TRH) 投与によ る明らかな運動失調改善は認められず, 行動量の増加も みられない。WMS は従来から報告されている遺伝性琿
動失調マウスとはかなり巽なった病態を示すことから， その運動障害の発症機構が異なる可能性が推定される。

\section{謝 辞}

動物供給にご協力下さいました北里大医学部大 沢 伸考 先 生, 大村実䮖動物例究所大村道夫氏に深謝いたします。

\section{文献}

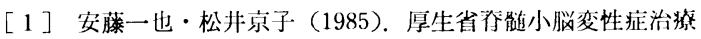
剂開発研究㙇. 昭和59年度研究業績. 138-141.

[2] Ando, K., and Matsui, K. (1986). TRH and spinocerebellar degeneration. Sobue, I. (Ed.) Elsevier Science Publishers BY (Biomedical Division).

[3] Honma, M., Satoh, T., Takezawa, J., and Ui, M. (1977). Biochen. Med., 18, 257-273 (1977).

[4]松井京子・真野行正・向山昌邦 - 村本 治 - 豊島 英徳 • 安藤一也 (1983). 実験動物, 32, 13-19.

[ 5 ] 松井京子.安藤一也 (1984). 実験動物, 33, 465-469.

[6] 松井京子 (1985). 実験動物, 35, 29-33.

[7] Miyamoto, M., and Nagawa, Y. (1977). Eur. J. Pharmacol, 44, 143-152.

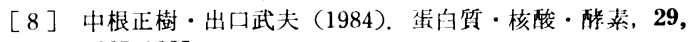
$1267-1285$. 